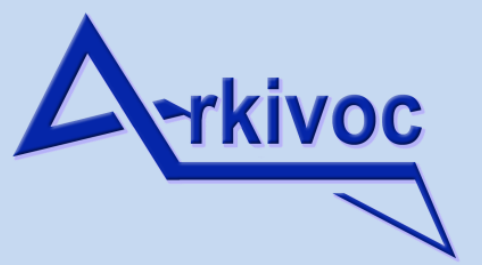

Archive for

Organic Chemistry
The Free Internet Journal

for Organic Chemistry
Paper

Arkivoc 2018, part v, 0-0

\title{
Activation of 6-bromoquinoline by nitration: synthesis of morpholinyl and piperazinyl quinolines
}

\author{
Osman Çakmak ${ }^{* a}$, Salih Ökten ${ }^{b}$, Dilek Alımlıc, Aisha Saddiqad, and Cem Cüneyt Ersanlı $^{\mathrm{e}}$ \\ ${ }^{a}$ Department of Chemisty, Faculty of Science, Yıldız Technical University, 34220 istanbul, Turkey \\ ${ }^{b}$ Department of Mathematic and Science Education, Division of Science Education, Faculty of Education, \\ Kırıkkale University, 71450, Yahşihan, Kırıkkale, Turkey \\ 'Department of Chemistry, Faculty of Science, Gebze Technical University, 41400, Gebze, Kocaeli, Turkey \\ ${ }^{d}$ Department of Chemistry, Faculty of Natural Science, Government College Women University, Sialkot, \\ Pakistan \\ ${ }^{e}$ Department of Physics, Faculty of Arts and Science, Sinop University, 570109, Sinop, Turkey \\ Email: cakmak.osman@gmail.com
}

Received 10-25-2017

Accepted 02-17-2018

Published on line 05-29-2018

\section{Abstract}

Quinoline forms the key skeletal component of a number of important natural products and pharmacologicallyactive compounds. Despite a tremendous amount of research pertaining to the derivatization of quinoline, very few general synthetic routes are described in the literature starting from quinoline or tetrahydroquinoline. A simple and convenient method for the polyfunctionalization of quinolines via nitration of bromoquinolines has been developed. This method represents a new synthetic approach to convert brominated nitroquinoline derivatives into useful cyclic amines via nucleophilic-substitution $\left(\mathrm{S}_{N} \mathrm{Ar}\right)$ reaction.

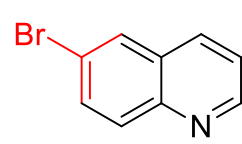

C-6, inactive for -NR substitution

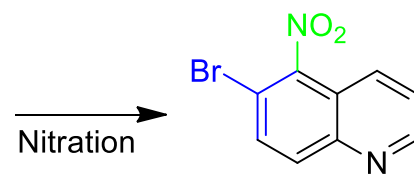

C-6, activated by $-\mathrm{NO}_{2}$ group

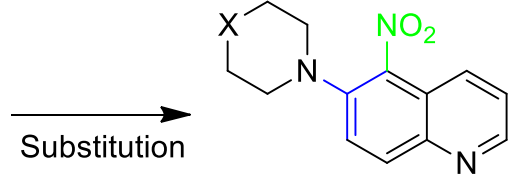

$\mathrm{X}=\mathrm{O} / \mathrm{NH}$

Keywords: Nitration, N-oxidation, 6-bromoquinoline, aminoquinoline, quinoline $\mathrm{N}$-oxides, morpholinyl and piperazinyl quinolines. 


\section{Introduction}

We have recently explored a new synthetic strategy for the synthesis of 6,8-dibromo-1,2,3,4tetrahydroquinoline (2), 6-bromo-1,2,3,4-tetrahydroquinoline (3) and 3,6,8-tribromoquinoline (4) based on the bromination reaction of substituted or unsubstituted 1,2,3,4-tetrahydroquinolines (1), good starting materials with functionality on both rings of quinoline. ${ }^{1-2}$ The direct halogenation of quinoline and tetrahydroquinoline seems the most attractive, however, it is still a challenging strategy as haloquinolines are also the best precursors of many other derivatives. In our previous publications, brominated tetrahydroquinolines were transformed into their respective derivatives (Scheme 1). ${ }^{3-4}$ Bromination of cyano- and methoxy- 1,2,3,4tetrahydroquinoline $(\mathbf{5}, \mathbf{7}$, and $\mathbf{8})$ gave their corresponding 3-brominated quinoline derivatives $(\mathbf{6}$, and $\mathbf{9 - 1 2}$, respectively) (Scheme 1)..$^{4-5}$ We found that methoxy 1,2,3,4-tetrahydroquinolines $(\mathbf{7}, \mathbf{8})$ were brominated not only at the $\mathrm{C}-3$, but also at the $\mathrm{C}-5$ positions, to give the corresponding bromoquinolines. ${ }^{5}$

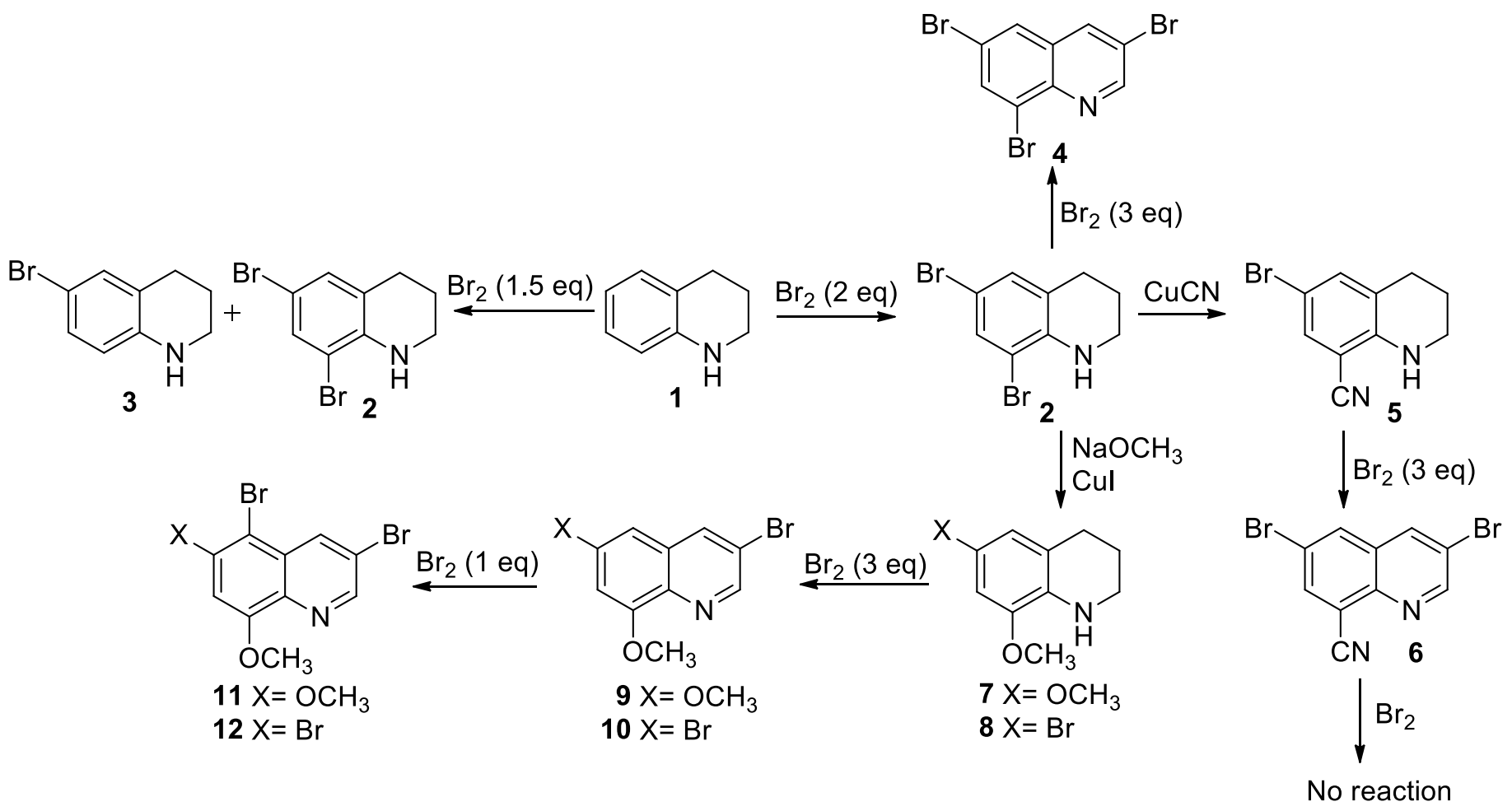

Scheme 1. Functionalization of substituted quinolines via bromination.

The quinoline moiety forms the key skeleton of several natural-product and pharmacologically-active compounds, displaying a broad spectrum of biological activities. ${ }^{6-9}$

We have investigated a new strategy for the polyfunctionalization of quinolines via nitration of bromoquinolines due to the fact that the nitro group has commonly activated adjacent bromo groups for nucleophilic substitution. Nitro groups are also good starting groups for amine formation.

6-Bromo-5-nitroquinoline (14) (DIE-17) exhibits high anti-proliferative, cytotoxic and apoptotic effects on several cancer-cell lines. ${ }^{10}$ Therefore, we planned to construct derivatives of (14) by simple substitution of the bromine with hetrocyclic rings. This substitution procedure would enable the introduction of heteroatoms via an $S_{N} A r$ method due to the activation of bromine group on the quinoline core by the nitro group, due to its 
strong electon-withdrawing effect, which could lead to other potentially bioactive molecules. e.g., (17) and (18) (Scheme 3).

It is evident from the literature that quinoline $\mathrm{N}$-oxide assists bromination and nitration reactions at the $\mathrm{C}$ 2 and C-4 positions. ${ }^{11}$ Halogenation at C-2 and nitration at C-4 or C-5 $5^{12}$ via the corresponding $\mathrm{N}$-oxides provides an important alternative route because $2-, 4-$, and 5 -substituted quinolines with $\mathrm{N}$-functionality are common themes in pharmacologically-active molecules. This led us to focus on the synthesis of bromo- and nitroderivatives of quinolines at the $\mathrm{C}-2, \mathrm{C}-4$ and $\mathrm{C}-5$ positions.

Although the piperazine- and morpholine-substituted quinolines have a wide range of biological importance, ${ }^{13-14}$ the available literature lacks syntheses of these piperazine- and morpholine-based derivatives on the benzene ring of quinolines by substitution methods.

Herein we report our prelimenary results for the synthesis of morpholine-, piperazine- and aminosubstituted quinolines starting from 6-bromo-5-nitroquinoline (14) and $\mathrm{N}$-oxide derivatives. The work presented is a continuation of our ongoing research and focuses on the synthesis of polyfunctional quinolines, starting from bromoquinolines. We are also interested in the biological activity and structure-activity relationship (SAR) of the synthesized compounds as many quinoline derivatives have exhibited promising pharmacological activities. ${ }^{7,15-18}$

\section{Results and Discussion}

6-Bromoquinoline (13) was synthesized according to our previously reported procedures, starting from 1,2,3,4tetrahydroquinoline (1) (Scheme 1). ${ }^{1}$ Following nitration using a mixture of $\mathrm{HNO}_{3} / \mathrm{H}_{2} \mathrm{SO}_{4}$ at $0^{\circ} \mathrm{C}$ for one hour with stirring, (13) yielded 6-bromo-5-nitroquinoline (14) as the sole product in quantitative yield (Scheme 2). Actually, nitration of quinoline can lead to a multiplicity of products as also shown in Scheme 2 . The reaction proceeded smoothly, however, to selectively give (14). The nitro-group substituent results in activation of the bromine group in substitution reactions due to the electron-accepting nature of the nitro group. The $-R$ effect of the $\mathrm{NO}_{2}$ group favours the substitution reactions with bromine. Previously, our group has reported the synthesis of 6-bromo-5-nitroquinoline (14) and its biological activity as an abstract at the Third International Molecular Biology and Biotechnology Congress. ${ }^{10}$ 6-Bromo-5-nitroquinoline (14) (DIE-17) exhibits high antiproliferative, cytotoxic and appoptotic effects on several cancer cell lines. Synthesis of the compound was also later reported by Chuang et al. ${ }^{20}$

After selective synthesis of 6-bromo-5-nitroquinoline (14) and its successful isolation and characterization, (14) was subjected to nucleophilic-substitution reactions with morpholine and piperazine in microwave-assisted reaction conditions (Scheme 3). Activation of the benzene ring by introduction of the $-\mathrm{NO}_{2}$ group facilitated the subsequent substitution of the adjacent bromine atom by morpholine and piperazine due to its resulting electron- deficiency effect on the quinoline ring.

6-Bromo-5-nitroquinoline was treated with morpholine or piperazine in triethylamine under microwave conditions $\left(150 \mathrm{~W}\right.$ at $90-120^{\circ} \mathrm{C}$ ) which furnished morpholinyl (17) and piperazinyl (18) quinolines in high yields (98\% and $87 \%$, respectively). 


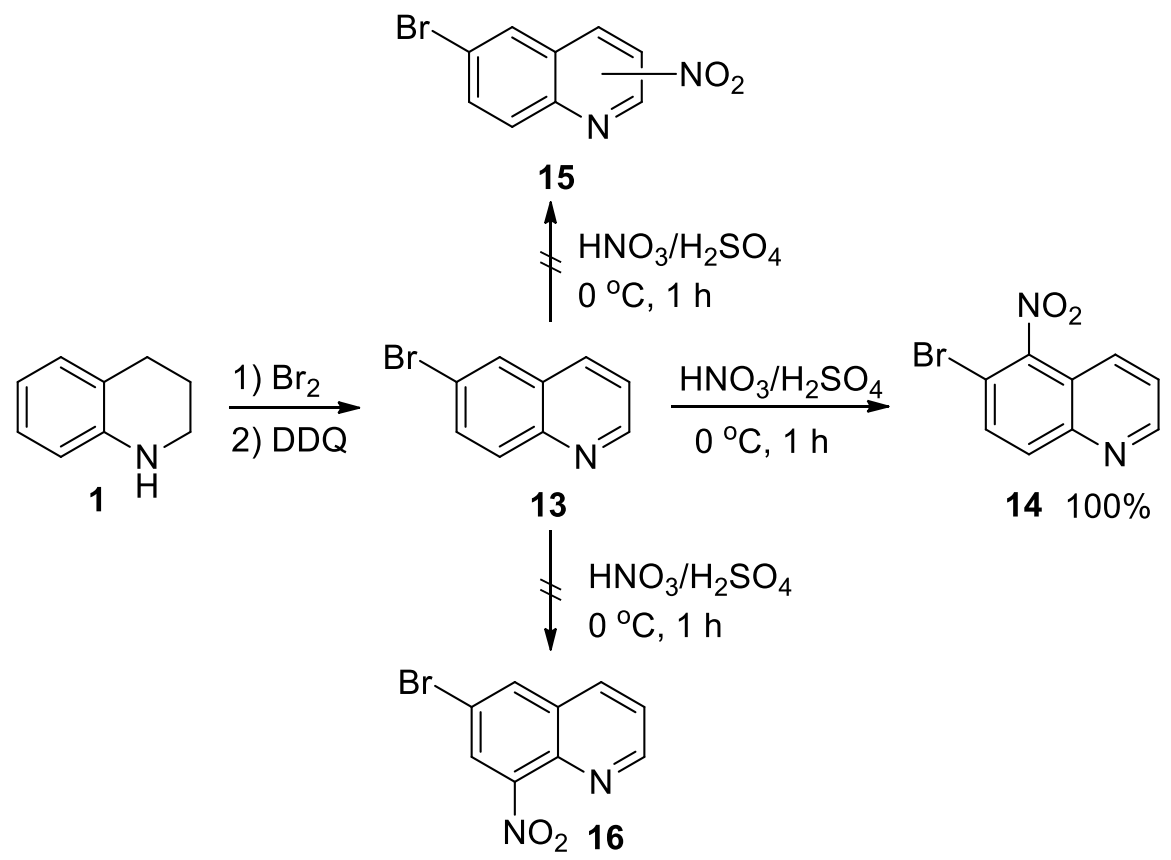

Scheme 2. Synthesis of (14) and possible other products of the nitration of (13).

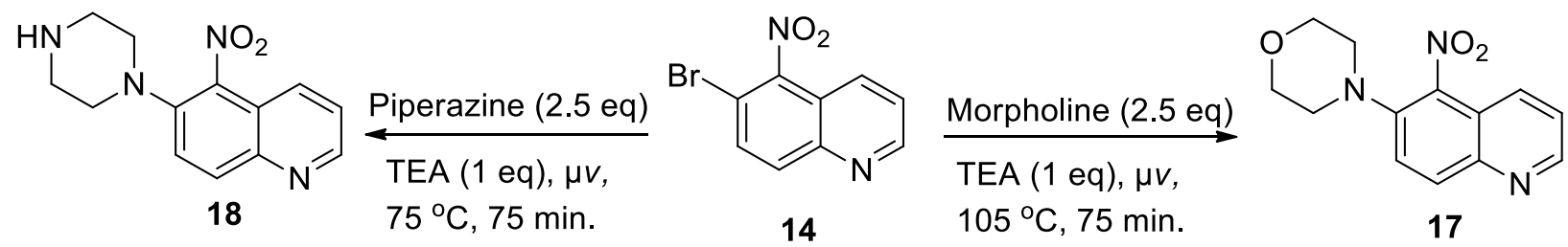

Scheme 3. Synthesis of morpholinyl- (17) and piperazinyl- (18) quinoline derivatives.

The formations of (17) and (18) were confirmed by ${ }^{1} \mathrm{H}$ and ${ }^{13} \mathrm{C}$ NMR spectral data. The appearance of aliphatic triplets in the ${ }^{1} \mathrm{H}$ NMR spectra of compound (17) (3.85 and 3.20 ppm, ${ }^{3} \mathrm{~J} 4.5 \mathrm{~Hz}$ ) and (18) (3.21 and $3.05 \mathrm{ppm},{ }^{3} \mathrm{~J}$ $4.5 \mathrm{~Hz}$ ) confirmed that morpholine and piperazine had replaced the bromine atom at $\mathrm{C}-6$. The additional singlet of $\mathrm{N}-\mathrm{H}$ appears at $2.51 \mathrm{ppm}$ in compound (18). The rest of the NMR spectrum is quite similar to that of the reactant (14) with a doublet for $\mathrm{H}-2$ at $8.87 \mathrm{ppm}\left({ }^{3} \mathrm{~J} 4.0 \mathrm{~Hz}\right.$ ), and doublets for $\mathrm{H}-7$ and $\mathrm{H}-8$ at 7.62 and $8.19 \mathrm{ppm}$ (3 $9.0 \mathrm{~Hz}$ ), respectively. The aromatic-region doublet of doublets at $\delta_{\mathrm{H}} 7.51 \mathrm{ppm}\left(J_{3,2} 8.5 \mathrm{~Hz}, J_{3,4} 4.0 \mathrm{~Hz}\right.$ ) belongs to $\mathrm{H}-3$. The appearance of two aliphatic (52.3 and $46.1 \mathrm{ppm}$ ) and nine aromatic carbons in ${ }^{13} \mathrm{C}$ NMR further confirmed the proposed structure of (18).

To afford the 2- and 4-nitro-substituted-bromoquinoline derivatives (22) and (23), it was first attempted to convert bromoquinolines (13) and (19) into the quinoline $N$-oxides (20) and (21), respectively (Scheme 4). which facilitated the nitration at the pyridine ring of the quinoline moiety due to $+\mathrm{R}$ effect of the $\mathrm{N}$-oxide form. The $\mathrm{N}$ oxidations of 6-bromo (13) and 6,8-dibromoquinoline (19) were carried out in the presence of $\mathrm{AcOH} / \mathrm{H}_{2} \mathrm{O}_{2}$ or $m$ CPBA (Scheme 5). Both $\mathrm{AcOH} / \mathrm{H}_{2} \mathrm{O}_{2}$ and $\mathrm{m}$-CPBA reacted smoothly with (13) and afforded the $\mathrm{N}$-oxide derivative (20) in good yield (60\% and $87 \%$, respectively). Several attempts to effect the same results for the $N$-oxidation of (19) to yield (21) failed, however, under the same or similar conditions. These attempts resulted in polymeric materials instead of the expected product. It is thought that the unsuccessful formation of the $N$-oxide (21) may have been the result of steric-hindrance effects of the bulky bromine group at C-8 (Scheme5). 

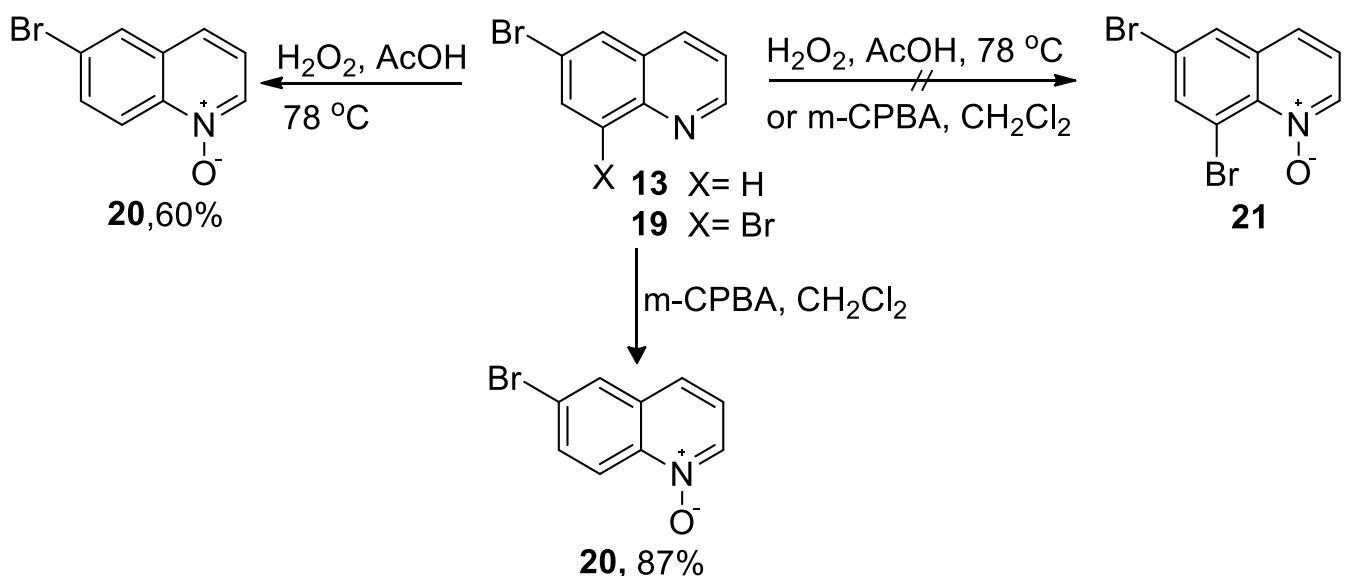

$20,87 \%$

Scheme 4. N-oxidation reactions of bromoquinolines (13) and (19).
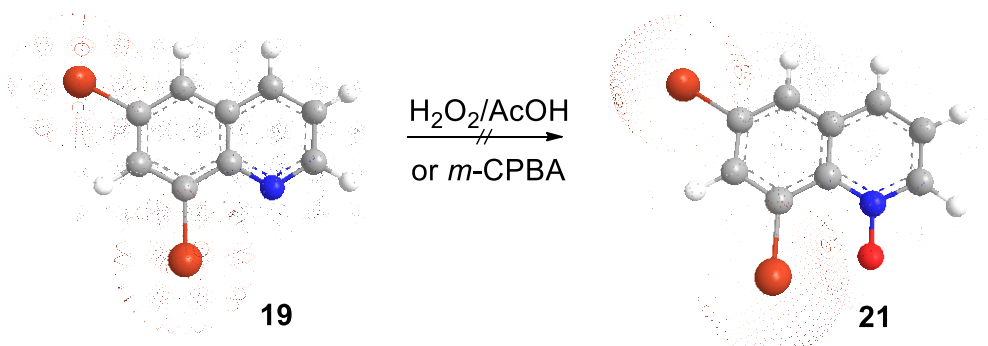

Scheme 5. Molecular models showing the possible steric-hindrance effect of the $\mathrm{C}-8 \mathrm{Br}$ group in the attempted formation of 6,8-dibromoquinoline-1-oxide (21).

The ${ }^{1} \mathrm{H}$ and ${ }^{13} \mathrm{C}$ NMR spectra of the 6-bromoquinoline-1-oxide (20) are quite similar to those of 6 bromoquinoline (13) with a little upfield shift of the aromatic protons of the pyridine ring and $\mathrm{H}-8$. The signal of $\mathrm{H}-5$ is a doublet at $\delta_{\mathrm{H}} 8.06(2.5 \mathrm{~Hz}$, meta coupling). The upfield shift of $\mathrm{H}-2$ of (20) compared with starting material (13), as expected, appears at $8.56 \mathrm{ppm}$ as a doublet $(6.0 \mathrm{~Hz})$. Due to the $\gamma$-gauche effect of the $\mathrm{N}$-O group, the signal of $\mathrm{H}-8$ shifts downfield (8.63 ppm, $9.2 \mathrm{~Hz}$ ) (Figure 1).

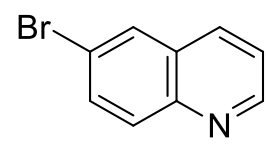

13

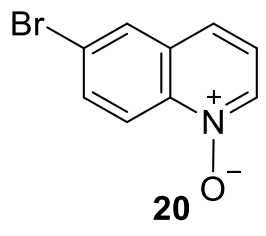

$\mathrm{H} 5=8.06(\mathrm{~d}, 1.9)$
$\mathrm{H} 8=8.63(\mathrm{~d}, 9.2)$
$\mathrm{H} 2=8.56(\mathrm{~d}, 6.0)$
$\mathrm{H} 7=7.84(\mathrm{dd}, 9.2,1.9)$
$\mathrm{H} 3=7.35(\mathrm{dd}, 8.4,6.0)$
$\mathrm{H} 4=7.68(\mathrm{~d}, 8.4)$

Figure 1. ${ }^{1} \mathrm{H}$ NMR values of compound (20) and its starting material (13).

Bromination of 6-bromoquinoline-1-oxide (20) has recently been reported. ${ }^{11}$ Therefore, we focused on the nitration of 6-bromoquinoline-1-oxide (20). The slow addition of a mixture of $\mathrm{HNO}_{3} / \mathrm{H}_{2} \mathrm{SO}_{4}$ to an ice-chilled solution of (20) provided a mixture of 5-nitro-6-bromoquinoline-1-oxide (25) and 4-nitro-6-bromoquinoline-1oxide (26). The products were isolated by column chromatography in yields of $57 \%$ and $29 \%$, respectively (Scheme 6). 


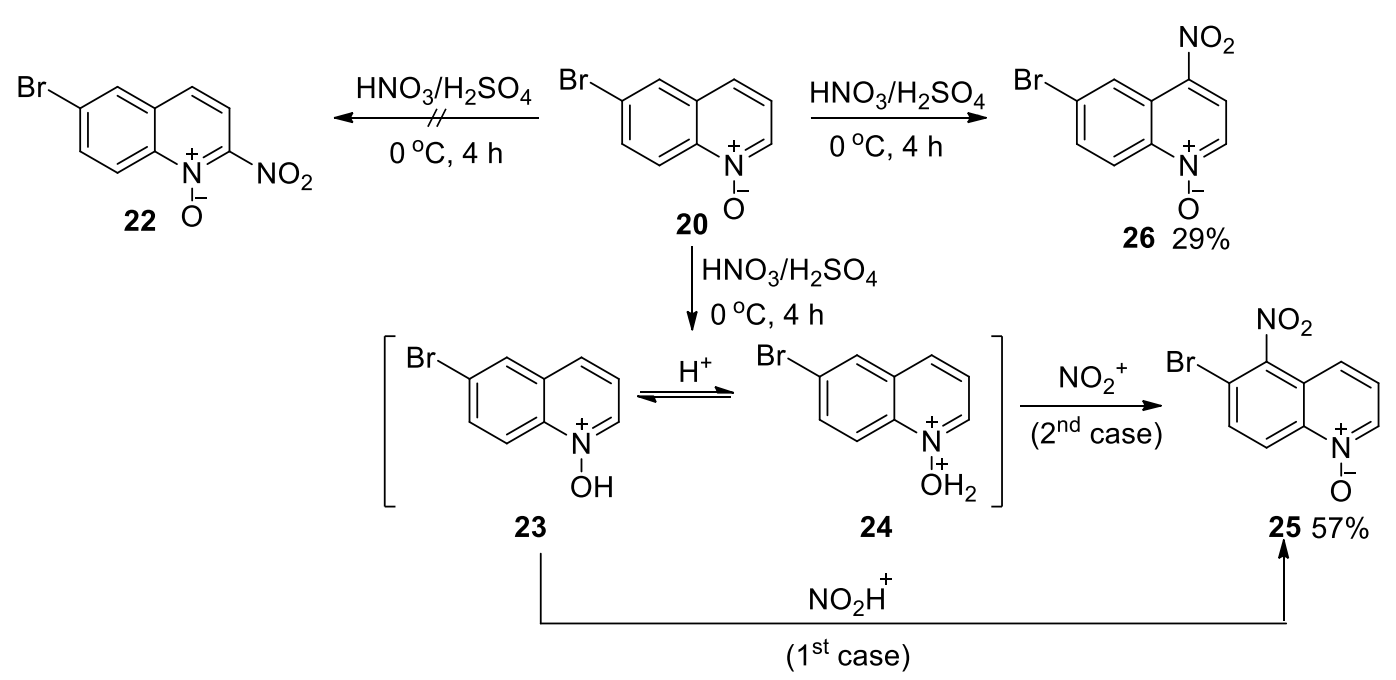

Scheme 6. Results of nitration of 6-bromoquinoline-1-oxide (20)

The proposed mechanism for the synthesis of (25) and (26) is represented in Scheme 6. In highly acidic conditions, strong nitrating agents prefer selectively the $\mathrm{C}-5$ position on quinoline $\mathrm{N}$-oxide. The reasons for the regioselectivity may be explained in two ways. First, the protonated nitronium ion contributes to regioselectivity at C-5 or the deprotonated quinoline-1-oxide (20) (Scheme 6). ${ }^{20-21}$ Alternatively, regioselectivity at C-5 may occur due to electrostatic repulsion between the electrophile and the positive charge of the oxonium ion of the 6-bromoquinoline $\mathrm{N}$-oxide (24) (Scheme 6). ${ }^{21}$ Some of the $\mathrm{N}$-oxide molecules are probably not protonated at low temperatures. For that reason, non-protonated $N$-oxides were nitrated at $\mathrm{C}-4$ in a small ratio.

The structures of 25 and 26 were characterized by FT/IR, ${ }^{1} \mathrm{H} N M R,{ }^{13} \mathrm{C} N M R$, and elemental analysis. X-ray crystallography was also performed for $\mathbf{2 5}$. In the ${ }^{1} \mathrm{H}$ NMR spectra of $\mathbf{2 5}$ and 26, the disappearance of the doublets of $\mathrm{H}-5$ and $\mathrm{H}-4$ from starting compound $\mathbf{2 0}$ was good evidence for the formations of 25 and 26 , respectively. In the ${ }^{1} \mathrm{H}$ NMR spectra of $\mathbf{2 5}$, signals of $\mathrm{H}-8$ and $\mathrm{H}-2$ were observed downfield, having similar chemical-shift values as the starting molecule 20 , while the signal of $\mathrm{H}-\mathbf{7}(\delta 7.96)$ was observed more downfield due to the $\mathrm{NO}_{2}$ group in $\mathbf{2 5}$ (Figure 2).

In the ${ }^{1} \mathrm{H}$ NMR spectrum of 4-nitro-6-bromoquinoline-1-oxide (26), $\mathrm{H}-5\left(J_{57} 2.0 \mathrm{~Hz}\right)$ shifted more downfield $\left(\delta_{\mathrm{H}}\right.$ 9.11) due to the gamma gauche effect of the $\mathrm{NO}_{2}$ group bonded at $\mathrm{C}-4$ (Figure 2). While $\mathrm{H}-7$ gave a doublet of doublets signal ( ${ }^{3} \mathrm{~J} 9.3$ and ${ }^{4} \mathrm{~J} 2.0 \mathrm{~Hz}$ ) at $7.96 \mathrm{ppm}$, the doublet signal of $\mathrm{H}-3\left({ }^{3} \mathrm{~J} 6.9 \mathrm{~Hz}\right)$ at 8.26 ppm was shifted more downfield compared to the signal of $\mathrm{H}-3(\delta 7.35,3 \mathrm{~J} 8.4$ and $6.0 \mathrm{~Hz})$ of starting material 20 . This evidence indicated that a $\mathrm{NO}_{2}$ group was bonded to 6-bromoquinoline-1-oxide (20) at the C-4 position.

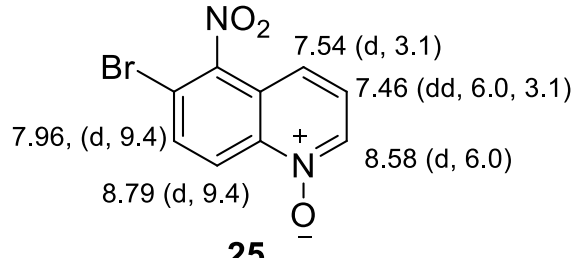

25

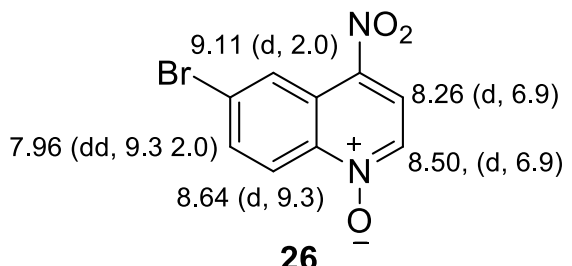

26

Figure 2. ${ }^{1} \mathrm{H}$ NMR values and coupling constants of 5-nitro-6-bromoquinoline-1-oxide (25) and 4-nitro-6bromoquinoline-1-oxide (26).

The structure of compound $\mathbf{2 5}$ was confirmed by X-ray diffraction studies (Table 1 and Figure 3 ). The dihedral angle between pyridine rings (C1-C4/C9/N1 and C19-C22/C27/N5) and phenyl rings (C4-C9 and C22-C27) for (I) 
and (III) is $0^{\circ}$. The dihedral angle between pyridine rings [(C10-C13/C18/N3) with a maximum deviation of $0.0062(1) \AA$ for $\mathrm{C} 18]$ and phenyl rings [(C13-C18) with a maximum deviation of $0.0068(1) \AA$ for $\mathrm{C} 16]$ is $0.80^{\circ}$ for (II). The C-N, C-Br, and N-O bond distances [1.315(13), 1.488(11), 1.861(9), 1.277(10), and 1.197(6) $\AA$ for (I); 1.330(10), 1.480(8), 1.889(7), 1.310(8), and 1.213(8) Å for (II); and 1.325(12), 1.482(11), 1.898(8), 1.299(10), and 1.167(7) A for (III), respectively, are the most sensitive indicators of the formation of 25 . The carbon-carbon, carbon-nitrogen, and nitrogen-oxygen bond lengths in compound $\mathbf{2 5}$ are comparable with those reported for a similar structure. ${ }^{22}$ Interesting intermolecular $\mathrm{C}-\mathrm{H}$...Br and $\mathrm{C}-\mathrm{H}$...O interactions are observed in the crystal structure of $\mathbf{2 5}$ (Figure 3). All bond lengths are provided in the supporting material.

Table 1. Selected crystal data and structure-refinement parameters for $\mathbf{2 5}$

\begin{tabular}{|c|c|c|c|}
\hline \multicolumn{4}{|c|}{ Crystal data and structure- refinement parameters } \\
\hline Identification code & 25 & Identification code & 25 \\
\hline Crystal system & Orthorhombic & $\mu\left(\mathrm{mm}^{-1}\right)$ & 4.422 \\
\hline Space group & $\mathrm{Pmc}_{1}$ & $\vartheta$ range $(\stackrel{\circ}{)})$ & $2.886-28.337$ \\
\hline$a(\AA)$ & $13.6694(13)$ & Measured refls. & 78841 \\
\hline$b(\AA)$ & $9.6036(10)$ & Independent refls & 4108 \\
\hline$c(\AA)$ & $14.1177(16)$ & $R_{\text {int }}$ & 0.0464 \\
\hline$V\left(\AA^{3}\right)$ & $1853.3(3)$ & $S$ & 1.221 \\
\hline Z & 8 & $R 1 / w R 2$ & $0.0448 / 0.0751$ \\
\hline$D_{\mathrm{c}}\left(\mathrm{g} \mathrm{cm}^{-3}\right)$ & 1.929 & $\Delta \rho_{\max } / \Delta \rho_{\min }\left(\mathrm{e} \AA^{-3}\right)$ & $0.624 /-0.737$ \\
\hline
\end{tabular}

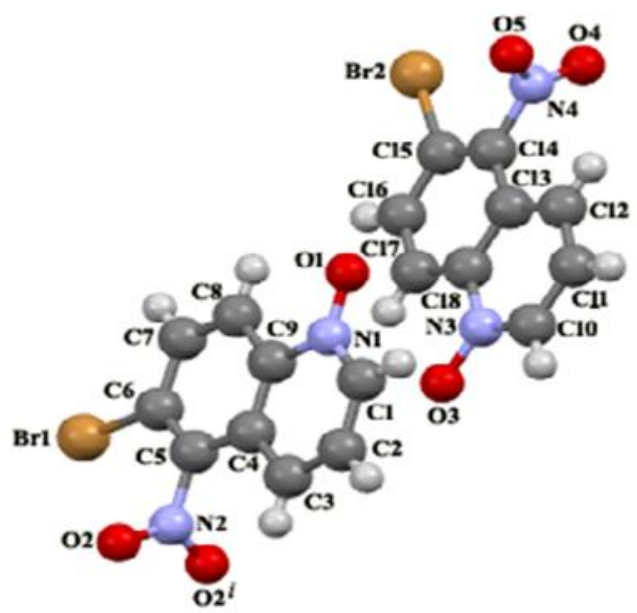

a

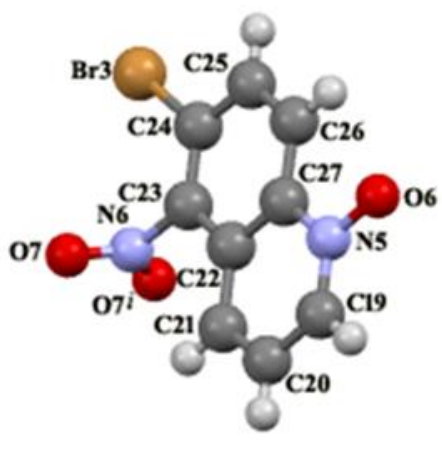

b

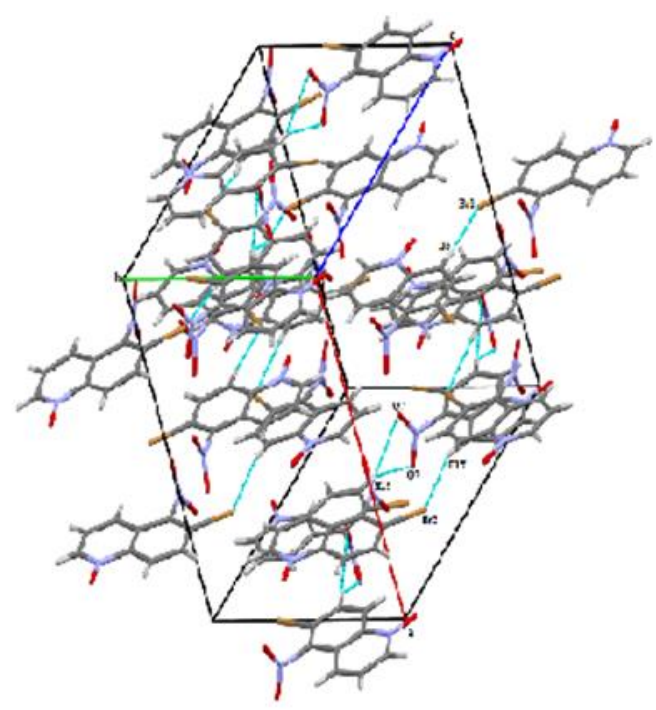

C

Figure 3. ORTEP diagram of $\mathbf{2 5}$ (a and $\mathbf{b}$ ); Crystal packing diagram of $\mathbf{2 5}$ (c).

Nitroquinolines are good precursors for amino-group derivatives. For this reason, the metal-based reduction of $\mathbf{2 5}$ was carried out in the presence of acetic acid. The reduction was performed by adding powdered metal (Fe) to the solution of 25 in aq. AcOH. After the addition of the metal, the mixture was stirred at $60{ }^{\circ} \mathrm{C}$ until the reactant disappeared on TLC. The extraction and normal work-up afforded $\mathbf{2 7}$ in $60 \%$ yield (Scheme 7).

We have also explored the deoxygenation of aromatic $N$-oxides using zinc dust (Scheme 7). The mixture of zinc and ammonium chloride in THF provides the mild conditions which furnished 5-amino-6-bromoquinoline 
(28) in high yield (81\%). The synthesis of 5-amino-6-bromoquinoline by reduction of 5-nitro-6-bromoquinoline (14) is already available in the literature, but in lower yield (68\%) as compared to our results.

The ${ }^{1} \mathrm{H}$ NMR spectrum of amino-substituent product 27 consists of the same signals with a shift upfield due to the electron-donating feature of the $\mathrm{NH}_{2}$ group. The successful reduction was inferred from the ${ }^{1} \mathrm{H} N M R$ spectrum showing a broad singlet of the two $-\mathrm{NH}_{2}$ protons. Moreover, the disappearance of an absorption signal of $N=\mathrm{O}$ and appearance of a new signal of $\mathrm{N}-\mathrm{H}$ stretching vibrations at $3420 \mathrm{~cm}^{-1}$ in the IR spectrum also provide clear evidence of formation of the reduced product 28 . The spectral values $\left({ }^{1} \mathrm{H},{ }^{13} \mathrm{C}\right.$ NMR and IR) of 5-amino-6bromoquinoline (28) corresponded with those in the literature. ${ }^{19}$
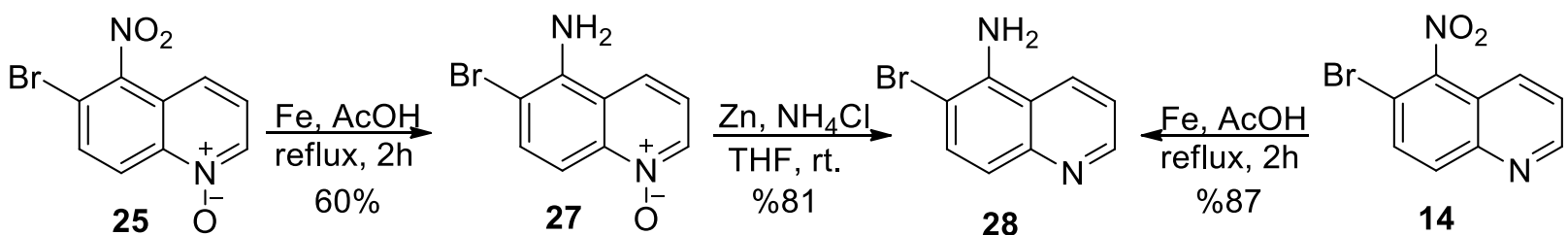

14

Scheme 7. Reduction reactions of $\mathbf{2 5}$ using Fe and of $\mathbf{2 7}$ using Zn.

\section{Conclusions}

A simple and convenient method for the polyfunctionalization of quinolines via nitration of bromoquinolines has been developed. This represents a new synthetic approach to convert brominated nitroquinoline derivatives into useful cyclic amines by nucleophilic-substitution $\left(S_{N} A r\right)$ reactions. We have developed a selective route for the synthesis of both 6-substituted morpholine and piperazine quinolines containing nitro substituents at the C-5 positions that could be converted to amino groups. The compounds exhibit high biological activities. ${ }^{23} 5-$ Nitro-6-bromoquinoline was found to be highly reactive towards $S_{N} A r$ nucleophilic substitution and investigations are ongoing regarding the generality and application of this approach to other bromoquinoline derivatives. On the other hand, the activation of the quinoline ring at different positions to obtain novel quinoline derivatives was enabled by $N$-oxidation of 6-bromoquinoline using $m$-CPBA.

\section{Experimental Section}

General. Thin-layer chromatography was carried out on Merck silica $F_{254}$ 0.255-mm plates, and spots were visualized by UV at $254 \mathrm{~nm}$. Flash column chromatography was performed using Merck 60 (70-230 Mesh) silica gel. The microwave reactions were run in a CEM Discover Labmate instrument. Melting points were determined on a Thomas Hoover Capillary Melting Point Apparatus. Solvents were removed under reduced pressure. IR spectra were recorded on a Jasco $430 \mathrm{FT} / \mathrm{IR}$ instrument. High-resolution Mass spectra (HRMS) were recorded on a mass spectrometer under electron-impact (EI) and chemical-ionization conditions. Elemental analysis was recorded on an Elementar Vario MICRO Cube instrument. NMR spectra were recorded on a Bruker $500 \mathrm{MHz}$ for ${ }^{1} \mathrm{H}$ and at $125 \mathrm{MHz}$ for ${ }^{13} \mathrm{C}$ NMR.

Synthesis of 6-Bromo-5-nitroquinoline (14). 6-Bromoquinoline (13) (0.190 g, $0.932 \mathrm{mmol})$ was dissolved in 4 $\mathrm{mL}$ of sulphuric acid, and cooled at $-5^{\circ} \mathrm{C}$ with a salt-ice bath. A mixture of $\mathrm{H}_{2} \mathrm{SO}_{4}(1.5 \mathrm{~mL})$ and $\mathrm{HNO}_{3}(1.5 \mathrm{~mL})$ acid 
was prepared and the acid mixture was cooled at $-5^{\circ} \mathrm{C}$. The solution obtained was cooled at $0{ }^{\circ} \mathrm{C}$ on a salt-ice bath. While the 6-bromoquinoline (13) solution was stirred with a magnetic stirrer, the $\mathrm{H}_{2} \mathrm{SO}_{4} / \mathrm{HNO}_{3}$ mixture was added dropwise with the aid of a Pasteur Pipette within one hour so the solution temperature did not exceed $0{ }^{\circ} \mathrm{C}$. The dark brown color of the reaction solution turned into a dark yellow color. After one hour the reaction was compete. The reaction mixture was poured over crushed ice ( $20 \mathrm{~g})$ in a beaker. After the ice melted, the mixture was extracted with $\mathrm{CH}_{2} \mathrm{Cl}_{2}(5 \times 5 \mathrm{~mL})$. The organic phase was neutralized with a $\mathrm{NaHCO}_{3}(10 \%)$ solution and dried over $\mathrm{Na}_{2} \mathrm{SO}_{4}$. The solvent was removed in-vacuo. Yellow-colored needle crystals were obtained as the sole product in quantitative yield $(0.23 \mathrm{~g}) . \mathrm{mp} 128-130^{\circ} \mathrm{C}$. IR (solid $\mathrm{KBr}, v \max , \mathrm{cm}^{-1}$ ): 3050,3019 , 2953, 2918, 2850, 1563, 1486, 1414, 1387, 1351, 1318, 1145, 1045, 831, 807, 755. ${ }^{1} \mathrm{H}$ NMR (500 MHz, ppm, $\left.\mathrm{CDCl}_{3}\right): \delta_{\mathrm{H}} 9.05\left(1 \mathrm{H}, \mathrm{dd}, J_{2,3} 4.2 \mathrm{~Hz}, J_{2,4} 1.6 \mathrm{~Hz}, \mathrm{H}-2\right), 8.15\left(1 \mathrm{H}, \mathrm{d}, J_{7,8} 9.0 \mathrm{~Hz}, \mathrm{H}-7\right), 8.05\left(1 \mathrm{H}, \mathrm{d}, J_{4,3} 8.6 \mathrm{~Hz}, \mathrm{H}-4\right), 7.92$ $\left(1 \mathrm{H}, \mathrm{d}, J_{8,7} 9.0 \mathrm{~Hz}, \mathrm{H}-8\right), 7.61\left(1 \mathrm{H}, \mathrm{dd}, J_{3,4} 8.6 \mathrm{~Hz} ; J_{3,2} 4.2 \mathrm{~Hz}, \mathrm{H}-3\right) .{ }^{13} \mathrm{C}$ NMR $\left(125 \mathrm{MHz}, \mathrm{CDCl}_{3}\right): \delta_{\mathrm{c}} 152.1,146.6,133.3$, 132.9, 129.8, 123.8, 123.4, 121.4, 112.2 Anal. calcd for $\mathrm{C}_{9} \mathrm{H}_{5} \mathrm{BrN}_{2} \mathrm{O}_{2}$ (251.95): C, 42.72; $\mathrm{H}, 1.99 ; \mathrm{N}, 11.07$. Found: C, $42.54 ; \mathrm{H}, 2.03 ; \mathrm{N}, 11.12$.

Synthesis of 5-nitro-6-(morpholin-1-yl)quinoline (17). A mixture of 6-bromo-5-nitroquinoline (14) $(0.1 \mathrm{~g}, 0.395$ $\mathrm{mmol})$, morpholine $(0.103 \mathrm{~g}, 1.185 \mathrm{mmol})$ and triethylamine $(0.040 \mathrm{~g}, 0.395 \mathrm{mmol})$ was heated slowly to $80{ }^{\circ} \mathrm{C}$ over $30 \mathrm{~min}$ while stirring. The open reaction vessel was placed into the microwave cavity. Microwave irradiation of $150 \mathrm{~W}$ was used and the temperature was ramped from room temperature to the desired temperature of 90-119 ${ }^{\circ} \mathrm{C}$. The reaction mixture was stirred continuously under microwave irridation at an average of $105^{\circ} \mathrm{C}$ for $45 \mathrm{~min}$. The reaction mixture was cooled to room temperature and taken up in $\mathrm{CH}_{2} \mathrm{Cl}_{2}(15 \mathrm{~mL})$. The organic layer was washed with $5 \%$ aq $\mathrm{NaHCO}_{3}(40 \mathrm{~mL})$ and dried over anhydrous $\mathrm{Na}_{2} \mathrm{SO}_{4}$. The solvent was removed under reduced pressure. The crude product was filtered by a short silica gel column eluted with a mixture of $n$ hexane/EtOAc (1:1) to afford the desired yellow solid product (116 mg, 98\% yield). mp 95-97 ${ }^{\circ} \mathrm{C}$. IR (solid $\mathrm{KBr}$, vmax, cm$\left.{ }^{-1}\right):$ 2967, 2916, 2895, 2854, 1738, 1620, 1589, 1341, 1262, 1211, 1068, 869, 815, 780, 731. ${ }^{1} \mathrm{H}$ NMR (500 MHz, CDCl 3 ): $\delta_{H} 8.90\left(1 \mathrm{H}, \mathrm{dd},{ }^{4}\right.$ J $\left.1.5 \mathrm{~Hz} ; 4.5 \mathrm{~Hz}, \mathrm{H}-2\right), 8.21\left(1 \mathrm{H}, \mathrm{d},{ }^{3} \mathrm{~J} 9.0 \mathrm{~Hz}, \mathrm{H}-4\right), 8.06\left(1 \mathrm{H}, \mathrm{d},{ }^{3} \mathrm{~J} 9.0 \mathrm{~Hz}, \mathrm{H}-8\right)$, $7.63\left(1 \mathrm{H}, \mathrm{d},{ }^{3} \mathrm{~J} 9.0 \mathrm{~Hz}, \mathrm{H}-7\right), 7.53\left(1 \mathrm{H}, \mathrm{dd},{ }^{3} \mathrm{~J} 9.0 \mathrm{~Hz} ; 4.5 \mathrm{~Hz}, \mathrm{H}-3\right), 3.85\left(4 \mathrm{H}, \mathrm{t}^{3}{ }^{3} \mathrm{~J} 4.5 \mathrm{~Hz}\right), 3.20\left(4 \mathrm{H}, \mathrm{t},{ }^{3} \mathrm{~J} 4.5 \mathrm{~Hz}\right) .{ }^{13} \mathrm{C}$ NMR $\left(125 \mathrm{MHz}_{1} \mathrm{CDCl}_{3}\right): \delta_{\mathrm{C}} 150.0,144.1,142.2,139.9,133.5,129.5,123.8,123.4,121.5,66.7,51.8$. HRMS for $\left(\mathrm{C}_{13} \mathrm{H}_{13} \mathrm{~N}_{3} \mathrm{O}_{3}[\mathrm{M}+\mathrm{H}]^{+}\right)(\mathrm{ESI}, \mathrm{m} / z)$. Calcd: 260.0994 . Found: 260.1035

Synthesis of 5-nitro-6-(piperazin-1-yl)quinoline (18). A mixture of 6-bromo-5-nitroquinoline (14) $(0.118 \mathrm{~g}, 0.446$ $\mathrm{mmol})$, piperazine $(0.115 \mathrm{~g}, 1.39 \mathrm{mmol})$, and triethylamine $(0.045 \mathrm{~g}, 0.446 \mathrm{mmol})$ was heated slowly to $80{ }^{\circ} \mathrm{C}$ over 30 min while stirring. The open reaction vessel was placed into the microwave cavity. Microwave irradiation of $150 \mathrm{~W}$ was used and the temperature ramped up from room temperature to the desired temperature of 68$78{ }^{\circ} \mathrm{C}$. The reaction mixture was stirred continuously under microwave irradiation at average $74{ }^{\circ} \mathrm{C}$ for $45 \mathrm{~min}$. The reaction mixture was cooled to room temperature and taken up in $\mathrm{CH}_{2} \mathrm{Cl}_{2}(25 \mathrm{~mL})$. The organic layer was washed with $5 \%$ aq $\mathrm{NaHCO}_{3}(50 \mathrm{~mL})$ and dried over anhydrous $\mathrm{Na}_{2} \mathrm{SO}_{4}$. The solvent was removed under reduced pressure. The crude product was filtered by a short silica gel column eluting with $\mathrm{MeOH}$ to afford the brown oil product (87\%; $0.100 \mathrm{~g}$ ). Rf 0.19 (MeOH). IR (solid KBr, vmax, $\mathrm{cm}^{-1}$ ): 3320, 2836, 1620, 1513, 1495, 1343, 1248, 1138, 1014, 978, 831, 795, 770, 541. ${ }^{1} \mathrm{H}$ NMR $\left(500 \mathrm{MHz}, \mathrm{CDCl}_{3}\right): \delta_{\mathrm{H}} 8.87\left(1 \mathrm{H}, \mathrm{d},{ }^{3} \mathrm{~J} 4.0 \mathrm{~Hz}, \mathrm{H}-2\right), 8.19$ (1H, d, 3J 9.0 $\mathrm{Hz}, \mathrm{H}-8), 8.06\left(1 \mathrm{H}, \mathrm{d},{ }^{3} \mathrm{~J} 8.5 \mathrm{~Hz}, \mathrm{H}-4\right), 7.62\left(1 \mathrm{H}, \mathrm{d},{ }^{3} \mathrm{~J} 9.0 \mathrm{~Hz}, \mathrm{H}-7\right), 7.51\left(1 \mathrm{H}, \mathrm{dd},{ }^{3} \mathrm{~J} 8.5 \mathrm{~Hz},{ }^{3} \mathrm{~J} 4.0 \mathrm{~Hz}, \mathrm{H}-3\right), 3.21(4 \mathrm{H}$, t, 3J $4.5 \mathrm{~Hz}), 3.05\left(4 \mathrm{H}, \mathrm{t},{ }^{3}\right.$ J $\left.4.5 \mathrm{~Hz}\right), 2.51(1 \mathrm{H}, \mathrm{s}, \mathrm{NH}) .{ }^{13} \mathrm{C} \mathrm{NMR}\left(125 \mathrm{MHz}, \mathrm{CDCl}_{3}\right): \delta_{\mathrm{C}} 149.7,143.8,142.8,139.1$, 133.4, 129.4, 124.2, 123.4, 121.6, 52.3, 46.1. HRMS for $\left(\mathrm{C}_{13} \mathrm{H}_{14} \mathrm{~N}_{4} \mathrm{O}_{2}[\mathrm{M}+\mathrm{H}]^{+}\right)(\mathrm{ESI}, \mathrm{m} / \mathrm{z})$. Calcd: 259.1195. Found: 259.1157.

Synthesis of 6-bromoquinoline-1-oxide (20). Method A: To a solution of 6-bromoquinoline (13) $(0.32 \mathrm{~g}, 1.54$ $\mathrm{mmol})$ in acetic acid $(20 \mathrm{~mL})$, hydrogen peroxide $(2 \mathrm{~mL})$ was added and stirred in an oil bath at reflux 
temperature for $2 \mathrm{~h}$. The reaction was monitored by thin layer chromatography (TLC) until consuming starting material. The solution was cooled at room temperature and diluted with distilled water ( $30 \mathrm{~mL}$ ). The pale yellow mixture was cooled to $-5{ }^{\circ} \mathrm{C}$ with mixture of salt and ice. The mixture was neutralized by adding a solution of $\mathrm{Na}_{2} \mathrm{CO}_{3}(10 \%)$ and extracted with $\mathrm{CH}_{2} \mathrm{Cl}_{2}(2 \times 25 \mathrm{~mL})$. The organic layer was dried over $\mathrm{Na}_{2} \mathrm{SO}_{4}$ and filtered. The solvent was evaporated to dryness under reduced pressure. A yellow solid was obtained (0.20 g, 60\%). Rf: 0.07 (3:1; EtOAc/ hexane).

Method B: To a solution of 6-bromoquinoline (13) $(0.73 \mathrm{~g}, 3.26 \mathrm{mmol})$ in cooled $\mathrm{CH}_{2} \mathrm{Cl}_{2}(43 \mathrm{~mL}), \mathrm{m}$ chloroperbenzoic acid ( $1.21 \mathrm{~g}, 7 \mathrm{mmol}$ ) was added and stirred at room temperature overnight. The reaction was monitored by TLC. The reaction mixture was diluted with $\mathrm{CH}_{2} \mathrm{Cl}_{2}(20 \mathrm{~mL})$ and extracted with $\mathrm{KOH}(6 \mathrm{~N}, 3 \times 15$ $\mathrm{mL}$ ). The organic layer was dried over $\mathrm{Na}_{2} \mathrm{SO}_{4}$ and filtered. The solvent was evaporated to dryness under reduced pressure. A yellow solid, $0.69 \mathrm{~g}$, (87\%) was obtained. Rf 0.15 in EtOAc. mp $131-133{ }^{\circ} \mathrm{C}$. IR (solid $\mathrm{KBr}, \mathrm{vmax}, \mathrm{cm}^{-}$ $\left.{ }^{1}\right)$ : 3289, 3092, 3067, 2920, 2850, 1560, 1590, 1142, 1064, 776, 732. ${ }^{1} \mathrm{H} \mathrm{NMR}\left(500 \mathrm{MHz}, \mathrm{CDCl}_{3}, \mathrm{ppm}\right): \delta_{\mathrm{H}} 8.63(1 \mathrm{H}$, d, ${ }^{3}$ J $\left.9.2 \mathrm{~Hz}, \mathrm{H}-8\right), 8.56\left(1 \mathrm{H}, \mathrm{d},{ }^{3}\right.$ J $\left.6.0 \mathrm{~Hz}, \mathrm{H}-2\right), 8.06\left(1 \mathrm{H}, \mathrm{d},{ }^{4} \mathrm{~J} 1.9 \mathrm{~Hz}, \mathrm{H}-5\right), 7.84\left(1 \mathrm{H}, \mathrm{dd},{ }^{3} \mathrm{~J} 9.2,{ }^{4} \mathrm{~J} 1.9 \mathrm{~Hz}, \mathrm{H}-7\right), 7.68$ $\left(1 \mathrm{H}, \mathrm{d},{ }^{3} \mathrm{~J} 8.4 \mathrm{~Hz}, \mathrm{H}-4\right), 7.35$ (1H, dd, 3J 8.4, ${ }^{3}$ J $\left.6.0 \mathrm{~Hz}, \mathrm{H}-3\right) .{ }^{13} \mathrm{C} \mathrm{NMR}\left(125 \mathrm{MHz}, \mathrm{CDCl}_{3}\right): \delta_{\mathrm{c}} 140.0,135.9,133.9$, 131.6, 130.1, 125.0, 123.3, 122.2, 121.8. Anal. calcd for $\mathrm{C}_{9} \mathrm{H}_{6} \mathrm{BrNO}$ (222.96): C, 48.25; H, 2.70; N, 6.25. Found: C, 48.12; H 2.83; N, 6.32 .

Nitration of 6-bromoquinoline-1-oxide (20). To the solution of 6-bromoquinoline-1-oxide (20) (1 eq, $0.6 \mathrm{~g}, 2.67$ $\mathrm{mmol}$ ) in $\mathrm{H}_{2} \mathrm{SO}_{4}(5 \mathrm{~mL})$ at $0{ }^{\circ} \mathrm{C}, \mathrm{HNO}_{3}(3 \mathrm{eq}, 0.8 \mathrm{~mL}$ ) was added drop-wise and stirred for $4 \mathrm{~h}$. The reaction mixture was poured onto ice and filtered. The solid mass was washed with $\mathrm{H}_{2} \mathrm{O}(3 \times 10 \mathrm{~mL})$ and the crude product purified by column chromatography. The elution with $5 \%$ EtOAc in $n$-hexane $(250 \mathrm{~mL})$ afforded 4-nitro-6-bromoquinoline 1-oxide (26) $(0.21 \mathrm{~g}, 29 \%)$ as a yellow powder, and, with crystallization with $8 \%$ EtOAc in $n$-hexane $(500 \mathrm{~mL})$, furnished 5-nitro-6-bromoquinoline 1-oxide (25) (0.41 g, 57\%).

6-Bromo-5-nitroquinoline 1-oxide (25) Yellow needles, $0.41 \mathrm{~g}$ (57\%), Rf 0.30 (EtOAc/hexane 3:7). mp 204-206 ${ }^{\circ} \mathrm{C}$. IR (solid KBr, vmax, $\mathrm{cm}^{-1}$ ): 3050 (aromatic C-H), 1480 (N-O), 700 (C-Br). ${ }^{1} \mathrm{H}$ NMR (500 MHz, CDCl 3 ): $\delta_{\mathrm{H}} 7.46$ $\left(1 \mathrm{H}, \mathrm{dd},{ }^{3} \mathrm{~J} 6.0 \mathrm{~Hz},{ }^{3} \mathrm{~J} 3.1 \mathrm{~Hz}, \mathrm{H} 3\right), 7.54\left(1 \mathrm{H}, \mathrm{d},{ }^{3} \mathrm{~J} 3.1 \mathrm{~Hz}, \mathrm{H} 4\right), 7.96\left(1 \mathrm{H}, \mathrm{d},{ }^{3}\right.$ J $\left.9.4 \mathrm{~Hz}, \mathrm{H} 7\right), 8.58\left(1 \mathrm{H}, \mathrm{d},{ }^{3}\right.$ J $\left.6.0 \mathrm{~Hz}, \mathrm{H} 2\right)$, $8.79\left(1 \mathrm{H}, \mathrm{d},{ }^{3} \mathrm{~J} 9.4 \mathrm{~Hz}, \mathrm{H8}\right) ;{ }^{13} \mathrm{C}$ NMR $\left(125 \mathrm{MHz}, \mathrm{CDCl}_{3}\right): \delta_{\mathrm{C}} 147.9,140.6,136.6,133.7,124.3,124.2,123.5,118.6$, 115.2. Anal. calcd for $\mathrm{C}_{9} \mathrm{H}_{5} \mathrm{BrN}_{2} \mathrm{O}_{3}$ (267.95): C, 40.18; $\mathrm{H}, 1.87 ; \mathrm{N}, 10.41$. Found: $\mathrm{C}, 40.28 ; \mathrm{H} 1.83 ; \mathrm{N}, 10.52$.

6-Bromo-4-nitroquinoline 1-oxide (26). Yellow powder $(0.21 \mathrm{~g}, 29 \%)$. mp 214-215 ${ }^{\circ} \mathrm{C}$. Rf 0.68 (EtOAc /hexane 3:7). IR (solid KBr, vmax, cm ${ }^{-1}$ ): 2995 (aromatic $\mathrm{C}-\mathrm{H}$ ), $1537(\mathrm{~N}-\mathrm{O}), 730(\mathrm{C}-\mathrm{Br}) .{ }^{1} \mathrm{H}$ NMR $\left(500 \mathrm{MHz}, \mathrm{CDCl}_{3}\right): \delta_{\mathrm{H}} 7.96$ $\left(1 \mathrm{H}, \mathrm{dd},{ }^{3} \mathrm{~J} 9.3,{ }^{4} \mathrm{~J} 2.0 \mathrm{~Hz}, \mathrm{H}-7\right), 8.26\left(1 \mathrm{H}, \mathrm{d},{ }^{3} \mathrm{~J} 6.9 \mathrm{~Hz}, \mathrm{H}-3\right), 8.50\left(1 \mathrm{H}, \mathrm{d},{ }^{3} \mathrm{~J} 6.9 \mathrm{~Hz}, \mathrm{H}-2\right), 8.64\left(1 \mathrm{H}, \mathrm{d}, 3^{3} \mathrm{~g} 9.3 \mathrm{~Hz}, \mathrm{H}-8\right)$, $9.11\left(1 \mathrm{H}, \mathrm{d},{ }^{4} \mathrm{~J} 2.0 \mathrm{~Hz}, \mathrm{H}-5\right) .{ }^{13} \mathrm{C}$ NMR $\left(125 \mathrm{MHz}, \mathrm{CDCl}_{3}\right): \delta_{c} 141.7,138.4,135.0,134.3,127.6,127.1,123.5,122.0$, 120.4. Anal. calcd for $\mathrm{C}_{9} \mathrm{H}_{5} \mathrm{BrN}_{2} \mathrm{O}_{3}$ (267.95): $\mathrm{C}, 40.18 ; \mathrm{H}, 1.87 ; \mathrm{N}, 10.41$. Found: $\mathrm{C}, 40.28 ; \mathrm{H} 1.83 ; \mathrm{N}, 10.52$.

Synthesis of 5-amino-6-bromoquinoline-1-oxide (27). To the stirring solution of 5-nitro-6-bromoquinoline 1oxide (25) (1 eq, $122 \mathrm{mg}, 0.045 \mathrm{mmol})$ in $\mathrm{H}_{2} \mathrm{O}(10 \mathrm{~mL})$, and one drop of $\mathrm{CH}_{3} \mathrm{COOH}(0.1 \mathrm{~mL})$ the powdered Fe $(6$ eq, $15.1 \mathrm{mg}, 0.27 \mathrm{mmol}$ ) was added and refluxed for $3 \mathrm{~h}$. The flask was removed and cooled to room temperature. The mixture was diluted with water $(30 \mathrm{~mL})$, extracted with EtOAC $(3 \times 10 \mathrm{~mL})$, dried over anhydrous $\mathrm{Na}_{2} \mathrm{SO}_{4}(5 \mathrm{~g})$, filtered, and the solvent was removed to afford the crude product (100 mg) which, upon further crystalization in $\mathrm{CH}_{2} \mathrm{Cl}_{2}(5 \mathrm{~mL})$, furnished the titled compound (27) as needle-like crystals. White needles

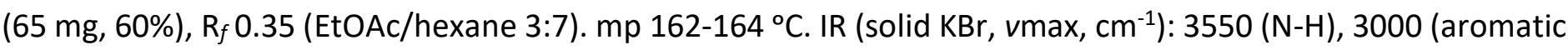
C-H) $1480(\mathrm{~N}-\mathrm{O}) .{ }^{1} \mathrm{H}$ NMR $\left(500 \mathrm{MHz}, \mathrm{CDCl}_{3}\right): \delta_{\mathrm{H}} 7.31\left(1 \mathrm{H}, \mathrm{dd},{ }^{3} \mathrm{~J} 4.0 \mathrm{~Hz},{ }^{3} \mathrm{~J} 8.5 \mathrm{~Hz}, \mathrm{H}-4\right), 7.38\left(1 \mathrm{H}, \mathrm{d}, 3^{3} \mathrm{~J} 9.5 \mathrm{~Hz}, \mathrm{H}-7\right)$, $7.64\left(1 \mathrm{H}, \mathrm{d},{ }^{3} \mathrm{~J} 9.0 \mathrm{~Hz}, \mathrm{H}-8\right), 8.10\left(1 \mathrm{H}, \mathrm{d},{ }^{3} \mathrm{~J} 8.5 \mathrm{~Hz}, \mathrm{H}-3\right), 8.83\left(1 \mathrm{H}, \mathrm{d},{ }^{3} \mathrm{~J} 4.0 \mathrm{~Hz}, \mathrm{H}-8\right), 4.65\left(\mathrm{~s}, 2 \mathrm{H}, \mathrm{NH}_{2}\right) .{ }^{13} \mathrm{C} \mathrm{NMR}(125$ $\left.\mathrm{MHz}, \mathrm{CDCl}_{3}\right): \delta_{\mathrm{C}} 149.0,140.9,135.4,132.4,130.2,120.8,109.7,104.3,102.6$. Anal. calcd for $\mathrm{C}_{9} \mathrm{H}_{7} \mathrm{BrN}_{2} \mathrm{O}$ (237.97): C, 45.22; H, 2.95; N, 11.72. Found: C, 45.28; H 2.98; N, 11.58. 
Synthesis of 5-amino-6-bromoquinoline (28). Method A: 6-Bromo-5-nitroquinoline (250 mg, $1.0 \mathrm{mmol}, 1.0 \mathrm{eq})$ was dissolved in $\mathrm{CH}_{3} \mathrm{COOH}(5 \mathrm{~mL})$. Fe powder $(335 \mathrm{mg}, 6.0 \mathrm{mmol}, 6.0 \mathrm{eq}$ ) was added and the reaction heated to approx. $75^{\circ} \mathrm{C}$ for $150 \mathrm{~min}$. Upon cooling, the mixture was filtered through filter paper and celite, and extracted with $\mathrm{CH}_{2} \mathrm{Cl}_{2}(3 \times 20 \mathrm{~mL})$ and a solution of $10 \%$ aq $\mathrm{Na}_{2} \mathrm{CO}_{3}(3 \times 15 \mathrm{~mL})$. The combined organic layers were washed with brine, dried over $\mathrm{Na}_{2} \mathrm{SO}_{4}$, and concentrated in vacuo. The crude material was purified by chromatography on silica gel (40\% EtOAc/60\% hexanes eluant) to provide 5-amino-6-bromoquinoline as a light yellow, amorphous solid (193 $\mathrm{mg}, 87 \%$ yield).

Method B: To a magnetically stirred suspension of the 5-amino-6-bromoquinoline 1-oxide (20) (1 eq, $1 \mathrm{mmol}$, $269 \mathrm{mg})$ and freshly activated Zinc dust $(4 \mathrm{mmol})$ in THF $(2 \mathrm{~mL})$ was added a saturated solution of ammonium chloride $(10 \mathrm{~mL})$. The resulting reaction mixture was stirred for $30 \mathrm{~min}$ at room temperature. The catalyst was removed by filtration and washed with $5 \%$ solution of $\mathrm{Na}_{2} \mathrm{CO}_{3}(10 \mathrm{~mL})$. The organic layer was dried over anhydrous $\mathrm{Na}_{2} \mathrm{SO}_{4}$. The residue obtained following evaporation of the solvent was purified by column chromatography on silica gel (EtOAc/hexane ; 3:7) to give the amorphous solid (28) (190 mg, $1 \mathrm{mmol}, 81 \%$ yield). IR (solid KBr, vmax, cm${ }^{-1}$ ): 3423, 3297, 3162, 1635, 1581, 1569, 1457, 1398, 1357, 1323. ${ }^{1} \mathrm{H} \mathrm{NMR}(500 \mathrm{MHz}$, $\left.\mathrm{CDCl}_{3}\right): \delta_{\mathrm{H}} 8.90\left(1 \mathrm{H}, \mathrm{dd},{ }^{3} \mathrm{~J} 4.5 \mathrm{~Hz},{ }^{4} \mathrm{~J} 1.5 \mathrm{~Hz}, \mathrm{H} 2\right), 8.18\left(1 \mathrm{H}, \mathrm{d},{ }^{3} \mathrm{~J} 8.5, \mathrm{H}-4\right), 7.71$ (d, 3J $\left.9.0 \mathrm{~Hz}, 1 \mathrm{H}, \mathrm{H}-8\right), 7.44\left(\mathrm{~d},{ }^{3} \mathrm{~J}\right.$ $9.0 \mathrm{~Hz}, 1 \mathrm{H}, \mathrm{H}-7), 7.39$ (dd, $\left.{ }^{3} \mathrm{~J} 8.5 \mathrm{~Hz}, 3 \mathrm{~J} 4.5 \mathrm{~Hz}, 1 \mathrm{H}, \mathrm{H}-3\right), 4.70\left(\mathrm{~s}, 2 \mathrm{H}, \mathrm{NH}_{2}\right) .{ }^{13} \mathrm{C} \mathrm{NMR}\left(125 \mathrm{MHz}, \mathrm{CDCl}_{3}\right.$, in ppm): $\delta_{\mathrm{C}}$ 150.3, 148.1, 139.6, 133.3, 129.4, 120.7, 120.2, 118.7, 104.3 (Lit ${ }^{19}$ ). Anal. calcd for $\mathrm{C}_{9} \mathrm{H}_{7} \mathrm{BrN}_{2}$ (221.98): C, 48.46; H, 3.16; N, 12.56. Found: C, 48.78; H 3.21; N, 12.37 .

Crystal structure determination for 6-bromo-5-nitroquinoline-1-oxide (25). A suitable sample of size $0.15 \mathrm{x}$ $0.11 \times 0.09 \mathrm{~mm}$ was selected for the crystallographic study. All diffraction measurements were performed at room temperature $\left(296^{\circ} \mathrm{K}\right)$ using graphite monochromatic MoK $\alpha$ radiation and a Bruker APEX-II CCD diffractometer. A total of 4795 reflections with $\left[2.886^{\circ}<\vartheta<28.337^{\circ}\right.$ ] were collected in the rotation mode and cell parameters were determined by using SAINT software. ${ }^{24}$ The structure was solved by direct methods using SHELXS-97. ${ }^{25}$ The refinement was carried out by full-matrix least-squares method on the positional and anisotropic temperature parameters of the non-hydrogen atoms, ${ }^{26}$ or equivalently corresponding to 311 crystallographic parameters. All non-hydrogen atom parameters were refined anisotropically and all $\mathrm{H}$ atom parameters were fixed to $0.93 \AA$ for $\mathrm{C}-\mathrm{H}$. The $U_{\text {iso }}$ values of $\mathrm{H}$ atoms were also fixed to 1.2 times the $U_{\text {eq }}$ value of parent atom for $\mathrm{C}-\mathrm{H}$. Other data-collection conditions and parameters of refinement process arepresented in Table 1.

\section{Acknowledgements}

This study was financially supported by grants from the Scientific and Technological Research Council of Turkey (TÜBITAK, Project number: 112T394). The authors thank the Scientific and Technological Research Application and Research Center, Sinop University, Turkey, for the use of the Bruker D8-QUEST diffractometer.

\section{Supplementary Materials}

Copies of ${ }^{1} \mathrm{H}$ NMR spectra of compounds 14, 17, 18, 20, 25, 26, 27 and 28 and ${ }^{13} \mathrm{C}$ NMR spectra of compounds 14, 17, 18, 20, 25 and 26 are represented in a Supplementary Materials Addendum.

An X-ray crystallographic file in CIF format, for the structure of compound 25 CCDC: 1525693 has been deposited with the Cambridge Crystallographic Data Center. The data can be obtained free of charge from The 
Cambridge Crystallographic Data Centre via http://www.ccdc.cam.ac.uk/data request/cif by e-mailing data requests @ccdc cam.ac.uk. or by contacting The Cambridge Crystallographic Data Centre, 12 Union Road, Cambridge CB2 1EZ, UK; fax: +44(0) 1223-33603.

\section{References}

1. Ökten, S.; Eyigün, D.; Çakmak, O. Sigma J. Eng. Nat. Sci. 2015, 33, 8.

2. Çelik, I.; Akkurt, M.; Ökten, S.; Çakmak, O.; Garcia-Granda, S.; Act Crys. Sec. E, 2010, E66, o3133.

3. Ökten, S.; Çakmak, O.; Erenler, R.; Tekin, Ş.; Yüce, Ö. Turk. J. Chem. 2013, 37, 896. https://doi.org/10.3906/kim-1301-30

4. Ökten, S.; Çakmak, O. Tetrahedron Lett. 2015, 56, 5337. https://doi.org/10.1016/j.tetlet.2015.07.092

5. Çakmak, O. Ökten, S.; Tetrahedron 2017, 73, 5389. https://doi.org/10.1016/j.tet.2017.07.044

6. Srivastava, S. K.; Chauhan, P. M. S.; Bhaduri, A. P.; Fatima, N.; Chatterjee, R. J. Med. Chem. 2000, $43,2275$. https://doi.org/10.1021/jm990438d

7. Zhang, N.; Wu, B.; Powell, D.; Wissner, A.; Floyd, M. B.; Kovacs, E. D.; Toralbarza, L.; Kohler, C. Bioorg. Med. Chem. Lett. 2000, 10, 2825. https://doi.org/10.1016/S0960-894X(00)00580-1

8. Muscia, G. C.; Bollini, M.; Carnevale, J. P.; Bruno, A. M.; Asis, S. E. Tetrahedron Lett. 2006, $47,8811$. https://doi.org/10.1016/j.tetlet.2006.10.073

9. Solomon, V. R.; Lee, H. Eur. J. Pharmacol. 2009, 625, 220. https://doi.org/10.1016/j.ejphar.2009.06.063

10. Ökten, S.; Eyigün, D.; Köprülü, T. K.; Çakmak, O.; Tekin, Ş. Third International Molecular Biology and Biotechnology Congress, Sarajevo, Bosnia and Herzegovina, June 02-06, 2014: Absract No. 244.

11. Wengryniuk, S. E.; Weickgenannt, A.; Reiher, C.; Strotman, N. A.; Chen, K.; Eastgate, M. D.; Baran, P.S. Org. Lett. 2013, 15, 792. https://doi.org/10.1021/ol3034675

12. Yokoyama, A.; Ohwada, T.; Saito, S.; Shudo, K. Chem. Pharm. Bull. 1997, 45, 279. https://doi.org/10.1248/cpb.45.279

13. Solomon, V. R.; Hu, C., Lee, H. Bioorg. Med. Chem. 2010, 18, 1563. https://doi.org/10.1016/j.bmc.2010.01.001

14. Salahuddin, A.; Inam, A.; Yan, Z. R.; Heslop, D. C.; Chen, C.; Avecilla, F.; Agarwal, M.; Azam, A. Bioorg. Med. Chem. 2013, 21, 3080. https://doi.org/10.1016/i.bmc.2010.01.001

15. Şahin, Ö. Y.; Ökten, S.; Tekin, Ş.; Çakmak, O. J. Biotech. 2012, Supplement 161, 24. https://doi.org/10.1016/i.jbiotec.2012.07.060

16. Ökten, S.; Şahin, Ö. Y.; Tekin, Ş.; Çakmak, O. J. Biotech. 2014, Supplement 185, 106. https://doi.org/10.1016/j.jbiotec.2014.07.359

17. Köprülü, T. K.; Tekin, Ş.; Ökten, S.; Çınar, M.; Duman, S.; Çakmak, O. J. Biotech. 2014, Supplement 185, 93. https://doi.org/10.1016/j.jbiotec.2014.07.318

18. Ökten, S.; Çakmak, O.; Tekin, Ş. Turk. J. Clin. Lab. 2017, 8, 152. https://doi.org/10.18663/tjcl.292058 
19. Chuang, K. V.; Kieffer, M. E.; Reisman S. E. Org. Lett. 2016, 18, 4750. https://doi.org/10.1021/acs.orglett.6b02477

20. Olah, G. A. Angew. Chem., Int. Ed. Engl. 1993, 32, 767. https://doi.org/10.1002/anie.199307673

21. Olah, G. A.; Orlinkov, A.; Qxyzoglou, A. B.; Prakash, G. K. S. J. Org. Chem. 1995, 60, 7348. https://doi.org/10.1021/jo00127a048

22. Tanak, H. J. Phys. Chem. A, 2011, 115, 13865. https://doi.org/10.1021/ip205788b

23. Ökten, S.; Alımlı, D.; Çakmak, O.; Köprülü, T. K.; Tekin, Ş.; Third International Drug and Pharmacy Congress, İstanbul, Turkey, April 26-29, 2017: Abstarct No. 135.

24. Bruker, 2014 APEX-II, SAINT, and SADABS. Bruker AXS Inc., Madison, Wisconsin, USA.

25. Sheldrick, G. M. Acta Cryst. A 2008, 64, 112.

26. Macrae C. F. ; Bruno, I. J. ; Chisholm, J. A. ; Edgington, P. R. ; McCabe, P. ; Pidcock E. ; Rodriguez-Monge, L. ; Taylor, R. ; Van de Streek, J. ; Wood, P. A. J. Appl. Cryst. 2008, 41, 466. 